\title{
English Textbook in Ethiopia from Teachers' and Students' Perspectives: The Case of Grade Twelve Students' Textbook
}

\author{
Abebe Tilahun \\ School of Languages and Communication Studies \\ Program of English Language and Literature \\ Hawasa University, Hawassa, Ethiopia \\ abebetilahun712@gmail.com
}

\begin{abstract}
This study investigates how teachers and students assess the English textbook they use in grade 12 at Addis Ketema Secondary and Preparatory School in Hawassa. Through a survey questionnaire and semistructured interview, four teachers and one hundred students were asked their perceptions of the textbook. The results showed that teachers and students had positive perceptions towards the textbook, English for Ethiopia grade 12. In addition, they gave constructive comments which were useful not only to streng then the good points of the textbook, but also to improve its weaknesses.

Though the textbook has many strong sides, both teachers and students point to some weaknesses in textbook in terms of its glossary list, shortage of time to cover the stated objectives, lack of models for final achievement tests, placing listening texts in the text book which would have been put in the teacher's guide and missing to include pronunciation lesson. In the light of these findings, the researcher reported some recommendations to address the slight drawbacks of the English Language textbook for grade 12.
\end{abstract}

Keywords: English Language Teaching, Evaluation of English Textbook, Teachers' and Students' perceptions, English for Ethiopia grade 12.

\section{INTRODUCTION}

English Language is so widely spoken; it has often been referred to as a "world language", the lingua franca of the modern era. Graddol (2000:2) states that English Language "is the main language of books, newspapers, airports and air traffic control, international business and academic references, science technology, diplomacy, sport, international competitions and advertising".

English as a foreign language (EFL) indicates the use of English in non-English-speaking regions. In Ethiopia, learning English occurs as part of the normal school curriculum. Barber (1993) states that in many areas, English is used as an official language. And it is thus taught as a subject starting from grade one in almost all elementary schools and as a medium of instructions in some regions (Addis Ababa, SNNPR) in Junior Secondary and in all high schools as well as higher institutions in Ethiopia.

One of the most important components of curriculum is the textbook which provides a clear framework that teachers and learners know where they are going and what is coming next, so that there is a sense of structure and progress. Ur (2006:184) mentions that "the textbook is the cheapest way of providing learning material for each learner; alternatives, such as kits, sets of photocopied papers or computer software, likely to be more expensive relative to the amount of material provided". Harmer (1991:257) also believes that textbooks supply attractive, interesting and lively materials which may not be produced by teachers.

Teachers, students, and textbooks are among the main elements of foreign or second language classrooms. For many years, the two elements, teachers and students and their roles were investigated thoroughly, but less attention was given to the issues regarding textbooks. However, in most cases, textbooks represent the hidden curriculum of the language studies in a certain program or country. For this reason, they play an important role for obtaining information about the likely teaching and learning practices of a particular school, program or institution (Richards, 2001)

On the other hand, McDonough and Tomlinson (1996) argues that the process of material evaluation can be seen as a way of developing our understanding of the way in which it works and in doing so of contributing to both acquisition and pedagogical practices. 
Textbooks are one of the teaching-learning elements of language. They have different contents, approaches and a target group to address and a goal to achieve. Regarding this idea Richards and Rodgers (2001) and Ur (1996) say Text books have positive and vital roles to play in the day to day language teaching and their importance has become even greater and larger from time to time. They are also critical ingredients in learning the intended curriculum.

\subsection{Statement of the Problem}

English, apart from being the medium of instruction in both high schools and higher educational institutions, is an important language of communication in the economic, political and social life of Ethiopia. To keep up the function effectively, a frequent assessment and study of the curriculum, the textbooks and the language teachers would contribute to the quality of education. It is for this general reason that ministry of Education has published English for Ethiopia grade1- 12 students' textbook which has been taught in almost all Ethiopian government schools since 2003/2004 E.C. Though this students' textbook for grade 12 was revised and has been implemented since 2003/2004 E.C, the level of its quality has not been evaluated so far as far as the researcher's experience is concerned. Thus it is timely to conduct this research.

There are various text book evaluation studies were conducted both locally and outside Ethiopia. Thus, over viewing some of the studies related to the purpose of this study is worthwhile. To begin with text book evaluation studies conducted outside Ethiopia, Abdulrahman Ali M. Alamri (2008) evaluated the Sixth Grade English Language Textbook for Saudi Boys' Schools; Hamad Al-sowat (2012) conducted study on Evaluation of English Language Textbook "Say It In English" For First Year Intermediate Grade in Saudi Arabia. In Ethiopia, HailuAbera (2008) evaluated the old English for Ethiopia grade 11 textbook and . Thus, this study will not be only different in setting and content from the above mentioned local and international research studies but also will fill the research gap that exists in English textbook evaluation in newly published grade 12 textbook.

\subsection{Purpose of the Study}

The purpose of this study is to assess the perception of teachers' and students' towards Grade 12 English for Ethiopia students' Textbook.

Specifically the study tries to answer the following two research questions

1. How do teachers assess grade 12 English for Ethiopia Students' textbook in terms of their Layout and physical appearance, Objectives, Activities and Tasks, Skills, Structure and vocabulary, Language, Subject and Content, and Culture?

2. How do students assess grade 12 English for Ethiopia Students' textbook in terms of their Layout and physical appearance, Objectives, Activities and Tasks, Skills, Structure and vocabulary, Language, Subject and Content, and Culture?

\section{REVIEW OF RELATED LITERATURE}

Textbook: Various scholars define textbook in various ways. Ur, (2006:183) for instance, define textbook as it is the course book which the teacher and, usually, each student has a copy, and which is in principle to be followed systematically as the basis for a language course. Moreover, "It is a guide for a teacher, a memory aid for the pupils and a permanent record or measure of what has been learnt" (Hutchinson and Torres, 1994:315). Hence, in this study, textbook is the formal written material published and printed by the Ministry of Education English for Ethiopia students' textbook grade 12.

Evaluation: The term evaluation has been used to define a variety of processes in the field of applied linguistics. Lynch (1996) defined evaluation as "the systematic attempt to gather information in order to make judgment or decisions" (p. 2). Harmer (2001) defines Course book evaluation, on the other hand, is a judgment on how well a book has performed in fact" (p. 301).

The Role of Textbooks in EFL Classrooms: English language teaching/learning has many important components but the essential one to many EFL classrooms is the textbook. Teachers feel that it is very difficult for them to teach systematically without a textbook. Indeed, the textbook plays a crucial role in providing a base of materials for both teachers and learners. With this regard, Sheldon (1988: 237) suggests that textbooks do not only represent the visible heart of any EFL program but also offer considerable advantages for both students and the teacher when they are being used in the ESL/EFL classrooms. Hutchinson and Torres (1994: 315) say that "the textbook is an almost universal element of teaching. 
Purpose of Textbook Evaluation: The idea of evaluating textbook is seen by some to be closely linked to the selection of textbook. Then evaluation helps the selection which serves as an important decision-making process. As Sheldon (1988) puts it: The selection of particular core volume signals as executive educational decision in which there is considerable professional financial and even political investment. The high profile means that the definition and application of system of systematic criteria for assessing course books are vita. (p.237)

Hutchinson (1987) suggests an interactive view of material evaluation. He emphasizes the deeper level of evaluation by asking the question why materials are the way they are. He claims that ... Material evaluation plays an important role in language teaching that is potential for influencing the way teachers operate is considerable. Materials evaluation can and should be a two-way process which enables teachers not just to select a textbook but also to develop their awareness of their own teaching/learning situation (Ibid: 37-38).

Evaluation of textbook is also considered to function as teacher development and professional growth. Cunnings worth (1995) and Ellis (1997) put forward that textbook evaluation helps teacher's move beyond impressionistic assessments and it helps them to acquire useful, accurate, systematic, and contextual insights into the overall nature of textbook evaluation. Textbook evaluation therefore can potentially be a particularly worthwhile means of conducting action research as well as a form of professional empowerment and improvement. Similarly textbook evaluation can also be a valuable component of teacher training program.

If one accepts the value of textbooks in ELT, then one should be able to trust that they are of an acceptable level of quality, usefulness, and appropriateness for the context and people with whom they are being used. Although Sheldon (1988) suggests that no general list of criteria can ever really be applied to all teaching and learning context without considerable modification, most of these standardized evaluation checklists contain similar components that can be used as helpful starting points for ELT practitioners in a wide variety of situations.

Preeminent theorists in the field of ELT textbook design and analysis, such as Cunningsworth (1995), Harmer (1996), McDonough and Shaw (1993) and Sheldon (1988), all agree for instance, that an evaluation checklist should have some criteria pertaining to the physical characteristics of textbooks such as layout, organizational, and logical characteristics. Other important criteria that should be incorporated are those that assess a textbook's methodology, aims, and approaches and the degree to which a set of materials is not only teachable but also fits the needs of the individual teacher's approach as well as organization's overall curriculum.

Moreover, criteria should analyze the specific language functions, grammar and skills content that are covered by a particular textbook, as well as the relevance of linguistic items to the prevailing sociocultural environment. Finally, textbook evaluation should include criteria to which linguistic items, subjects, content, and topics match up to students' personalities, background, needs and interests as well as those of the teacher/or institution.

\section{RESEARCH DESIGN AND METHODOLOGY}

Research Method: A survey was done to gather the information needed. This is a method of data gathering from samples which are representative of a population. Brown \& Rogers (2002) state "Surveys are any procedures used to gather and describe the characteristics, attitudes, views, opinions and so forth of students, teachers, administrators or any other people who are important to a study" (p. 142).

Sampling Size and Technique: Because of both the need for more reliable information and the nature of the study, information was collected from Addis Ketema Secondary and Preparatory grade 12 students, English teachers who are teaching the mentioned grade level.

With regard to students, of 8 sections 13 students were randomly selected from each section. Thus, of the total 400 students 104 students (26\%) were taken to fill the questionnaire and $100(25 \%)$ of them were filled and returned the question papers.

With regard to subject teachers' all of the four subject teachers teaching in grade 12 were used in this study using available sampling technique. 


\subsection{Instruments of Data Collection}

Questionnaire: Many scholars such as Cunnings worth (1995), Sheldon (1987), Ur (1996), Tomlinson (1998) and Richards (2001) suggested that in order to determine the relative strengths and weakness of the book and ultimately decide how well it suited the desired and attainable goals of the learners a series of textbook evaluation survey questionnaires should be used.

Therefore, two types of questionnaires were employed to conduct this study. The first one was for the students, and the second for the teachers. Most of the items in the questionnaires were adapted and modified from the checklists and criteria's used to evaluate ELT material by Sheldon (1987), Tomlinson (1998), Cunningsworth (1995), Harmer (1996) and Richards (2001), Dr.Hamad Al-sowat (2012), Abdulrahman Ali M. Alamri (2008) and HailuAbera (2008).

Interview: The second type of data collecting instrument used in this study was semi-structured interview. The purpose of the interview was to validate the data gathered through the questionnaire. Therefore, the content of the interview was similar to that of the questionnaire. According to Gay and Airasian (2000), semi-structured interview gives the researcher the freedom to direct the interview in a uniform fashion and sometimes allows the interviewees to 'frame' and structure their responses the way they wish to. The semi-structured interview was conducted with four English teachers working in the specified school.

Data Analysis and Interpretations: In this study, students and teachers perception towards grade 12 students' English for Ethiopia textbook is analyzed. The Grade 12 students' English for Ethiopia textbook is new. It was published in 2011 and prepared by the Federal Democratic Republic of Ethiopia, Ministry of Education. The textbook is printed in Malaysia and of colorful prints unlike the former one. There are also bundle of pictures used in the textbook.

Table1. Subjects' perception on layout and physical appearance of the textbooks

\begin{tabular}{|c|c|c|c|c|c|c|c|c|}
\hline No & Item & \multicolumn{2}{|c|}{ Respondents } & Strongly & Disagree & Undecided & Agree & Strongly agree \\
\hline \multirow[t]{4}{*}{1} & \multirow{4}{*}{$\begin{array}{l}\text { The textbook is } \\
\text { durable (Quality } \\
\text { of paper and } \\
\text { binding) }\end{array}$} & \multirow[t]{2}{*}{ Teachers } & $\mathrm{F}$ & 0 & 0 & 0 & 1 & 3 \\
\hline & & & $\%$ & 0 & 0 & 0 & 25 & 75 \\
\hline & & \multirow[t]{2}{*}{ Students } & $\mathrm{F}$ & 7 & 11 & 12 & 28 & 42 \\
\hline & & & $\%$ & 7 & 11 & 12 & 28 & 42 \\
\hline \multirow[t]{4}{*}{2} & \multirow{4}{*}{$\begin{array}{l}\text { The size of the } \\
\text { textbook seems } \\
\text { convenient for } \\
\text { students to } \\
\text { handle. }\end{array}$} & \multirow[t]{2}{*}{ Teachers } & $\mathrm{F}$ & 1 & 2 & 1 & 0 & 0 \\
\hline & & & $\%$ & 25 & 50 & 25 & 0 & 0 \\
\hline & & \multirow[t]{2}{*}{ Students } & $\mathrm{F}$ & 30 & 24 & 0 & 23 & 23 \\
\hline & & & $\%$ & 30 & 24 & 0 & 23 & 23 \\
\hline \multirow[t]{4}{*}{3} & \multirow{4}{*}{$\begin{array}{l}\text { The cover of the } \\
\text { textbook is } \\
\text { appealing. }\end{array}$} & \multirow[t]{2}{*}{ Teachers } & $\mathrm{F}$ & 0 & 0 & 0 & 2 & 2 \\
\hline & & & $\%$ & 0 & 0 & 0 & 50 & 50 \\
\hline & & \multirow[t]{2}{*}{ Students } & $\mathrm{F}$ & 5 & 4 & 2 & 60 & 29 \\
\hline & & & $\%$ & 5 & 4 & 2 & 60 & 29 \\
\hline \multirow[t]{4}{*}{4} & \multirow{4}{*}{$\begin{array}{l}\text { The textbook } \\
\text { contains enough } \\
\text { pictures, } \\
\text { diagrams, tables } \\
\text { etc. helping the } \\
\text { students } \\
\text { understand the } \\
\text { printed texts. }\end{array}$} & \multirow[t]{2}{*}{ Teachers } & $\mathrm{F}$ & 1 & 0 & 0 & 1 & 2 \\
\hline & & & $\%$ & 25 & 0 & 0 & 25 & 50 \\
\hline & & \multirow[t]{2}{*}{ Students } & $\mathrm{F}$ & 18 & 22 & 3 & 26 & 31 \\
\hline & & & $\%$ & 18 & 22 & 3 & 26 & 31 \\
\hline \multirow[t]{4}{*}{5} & \multirow{4}{*}{$\begin{array}{l}\text { An adequate } \\
\text { vocabulary list or } \\
\text { glossary is } \\
\text { included. }\end{array}$} & \multirow[t]{2}{*}{ Teachers } & $\mathrm{F}$ & 1 & 2 & 0 & 0 & 1 \\
\hline & & & $\%$ & 25 & 50 & 0 & 0 & 25 \\
\hline & & \multirow[t]{2}{*}{ Students } & $\mathrm{F}$ & 31 & 30 & 4 & 20 & 15 \\
\hline & & & $\%$ & 31 & 39 & 4 & 20 & 15 \\
\hline \multirow[t]{4}{*}{6} & \multirow{4}{*}{$\begin{array}{l}\text { The instructions } \\
\text { in the textbook } \\
\text { are written in a } \\
\text { simple and clear } \\
\text { language. }\end{array}$} & \multirow[t]{2}{*}{ Teachers } & $\mathrm{F}$ & 0 & 1 & 0 & 2 & 1 \\
\hline & & & $\%$ & 0 & 25 & 0 & 50 & 25 \\
\hline & & \multirow[t]{2}{*}{ Students } & $\mathrm{F}$ & 10 & 9 & 2 & 39 & 40 \\
\hline & & & $\%$ & 10 & 9 & 2 & 39 & 40 \\
\hline
\end{tabular}


On whether or not the cover of the book is durable or not, the results indicate that an extremely high percentage of the participants support the statement, $75 \%$ of teachers and $42 \%$ of students strongly agree and $25 \%$ of teachers and 28 of students agree, while, few number of the participants disagree with the statement. So, it can be said that the majority of the participants believe that the book is durable.

In contrast, in item 2 both teachers and students agree that the size of the textbook is not suitable for the students to handle.

The third question was on whether or not the cover of the book is appealing; the results indicate that nearly high percentage of the participants support the statement, $29 \%$ strongly agree and $60 \%$ agree, while, only 9 participants (9\%) disagree with the statement. So, it can be said that the majority of the participants believe that the cover of the textbook attractive.

Concerning the issue of whether or not the textbook contains enough pictures, diagrams, tables etc. helping the students understand the printed texts, table 1 shows that more than half of the subjects either agree or strongly agree on the statement.

Regarding the statement on whether or not the book has an appropriate glossary, the results show that more than $60 \%$ of the subjects are either disagree or strongly disagree. This indicates that both the students and teachers are not satisfied with the glossary provided in the students' text book.

Based on table 1 item 6, only $19 \%$ of the students and $33 \%$ of teachers are dissatisfied with the clarity and simplicity of the instructions. Whereas the majority of the students and teachers indicated that most of the instructions in the text book are clear and simple. Three of the interviewed teachers pointed out that the textbook has good layout and physical appearance.

Table2. Subjects' Perception on the Objectives of the Textbook

\begin{tabular}{|c|c|c|c|c|c|c|c|c|}
\hline No & Item & \multicolumn{2}{|c|}{ Respondents } & Strongly & Disagree & Undecided & Agree & Strongly agree \\
\hline \multirow[t]{4}{*}{7} & \multirow{4}{*}{$\begin{array}{l}\text { Objectives are } \\
\text { provided in units in } \\
\text { the textbook }\end{array}$} & \multirow[t]{2}{*}{ Teachers } & $\mathrm{F}$ & 0 & 0 & 0 & 1 & 3 \\
\hline & & & $\%$ & 0 & 0 & 0 & 25 & 75 \\
\hline & & \multirow[t]{2}{*}{ Students } & $\mathrm{F}$ & 4 & 3 & 2 & 44 & 47 \\
\hline & & & $\%$ & 4 & 3 & 2 & 44 & 47 \\
\hline \multirow[t]{4}{*}{8} & \multirow{4}{*}{$\begin{array}{l}\text { The objectives in } \\
\text { the textbook are } \\
\text { clear and precise for } \\
\text { the Learners }\end{array}$} & \multirow[t]{2}{*}{ Teachers } & $\mathrm{F}$ & 0 & 1 & 0 & 2 & 1 \\
\hline & & & $\%$ & 0 & 25 & 0 & 50 & 25 \\
\hline & & \multirow[t]{2}{*}{ Students } & $\mathrm{F}$ & 2 & 2 & 4 & 48 & 54 \\
\hline & & & $\%$ & 2 & 2 & 4 & 48 & 54 \\
\hline \multirow[t]{4}{*}{9} & \multirow{4}{*}{$\begin{array}{l}\text { The objectives can } \\
\text { be covered within } \\
\text { the time allocated } \\
\text { for the textbook. }\end{array}$} & \multirow[t]{2}{*}{ Teachers } & $\mathrm{F}$ & 1 & 2 & 1 & 0 & 0 \\
\hline & & & $\%$ & 25 & 50 & 25 & 0 & 0 \\
\hline & & \multirow[t]{2}{*}{ Students } & $\mathrm{F}$ & 35 & 30 & 20 & 15 & 0 \\
\hline & & & $\%$ & 35 & 30 & 20 & 15 & 0 \\
\hline
\end{tabular}

As it can be seen from Table 2, almost all participants of the study judged that the objectives are included in all units in the books. This indicates that learners are clear with what they are going to achieve at the end of each unit.

With regard to item number $8,50 \%$ and $25 \%$ teachers were agree and strongly agreed respectively. Only 25 of the teachers disagree. Besides, more than $90 \%$ of the students were agreed. From this we can deduce that a significant number of the participants agreed that the objectives were clear and precise for the learners.

As can be seen from table 2, majority (75\% of teachers and $65 \%$ of students) of the participants agree that the objectives could not be covered with in the time allocated for the text book.

In the interviews, all participants indicate that the objectives are included in all the units and they are clear and precise for the learners. In addition, majority of the interviewees claimed that they faced difficulties in covering all the contents within the given time. 
Table3. Subjects' Perception on the Activities and Tasks in the Textbook

\begin{tabular}{|c|c|c|c|c|c|c|c|c|}
\hline No & Item & \multicolumn{2}{|c|}{ Respondents } & Strongly & Disagree & Undecided & Agree & Strongly agree \\
\hline \multirow[t]{4}{*}{10} & \multirow{4}{*}{$\begin{array}{l}\text { There are } \\
\text { varieties of } \\
\text { activities }\end{array}$} & \multirow[t]{2}{*}{ Teachers } & $\mathrm{F}$ & 0 & 0 & 1 & 1 & 2 \\
\hline & & & $\%$ & 0 & 0 & 25 & 25 & 50 \\
\hline & & \multirow[t]{2}{*}{ Students } & $\mathrm{F}$ & 7 & 10 & 6 & 43 & 34 \\
\hline & & & $\%$ & 7 & 10 & 6 & 43 & 34 \\
\hline \multirow[t]{4}{*}{11} & \multirow{4}{*}{$\begin{array}{l}\text { The activities } \\
\text { encourage } \\
\text { meaningful } \\
\text { practice }\end{array}$} & \multirow[t]{2}{*}{ Teachers } & $\mathrm{F}$ & 0 & 0 & 0 & 3 & 1 \\
\hline & & & $\%$ & 0 & 0 & 0 & 75 & 25 \\
\hline & & \multirow[t]{2}{*}{ Students } & $\mathrm{F}$ & 15 & 15 & 10 & 35 & 25 \\
\hline & & & $\%$ & 15 & 15 & 10 & 35 & 25 \\
\hline \multirow[t]{4}{*}{12} & \multirow{4}{*}{$\begin{array}{l}\text { The activities } \\
\text { incorporate } \\
\text { individual, pair } \\
\text { and group work }\end{array}$} & \multirow[t]{2}{*}{ Teachers } & $\mathrm{F}$ & 0 & 1 & 0 & 2 & 1 \\
\hline & & & $\%$ & 0 & 25 & 0 & 50 & 25 \\
\hline & & \multirow[t]{2}{*}{ Students } & $\mathrm{F}$ & 2 & 2 & 4 & 48 & 54 \\
\hline & & & $\%$ & 2 & 2 & 4 & 48 & 54 \\
\hline \multirow[t]{4}{*}{13} & \multirow{4}{*}{$\begin{array}{c}\text { The activities are } \\
\text { stimulating }\end{array}$} & \multirow[t]{2}{*}{ Teachers } & $\mathrm{F}$ & 0 & 0 & 1 & 1 & 2 \\
\hline & & & $\%$ & 0 & 0 & 25 & 25 & 50 \\
\hline & & \multirow[t]{2}{*}{ Students } & $\mathrm{F}$ & 18 & 10 & 14 & 28 & 30 \\
\hline & & & $\%$ & 18 & 10 & 14 & 28 & 30 \\
\hline \multirow[t]{4}{*}{14} & \multirow{4}{*}{$\begin{array}{l}\text { There is a } \\
\text { balance between } \\
\text { the activities for } \\
\text { language and } \\
\text { activities for } \\
\text { skills. }\end{array}$} & \multirow[t]{2}{*}{ Teachers } & $\mathrm{F}$ & 0 & 0 & 0 & 2 & 2 \\
\hline & & & $\%$ & 0 & 0 & 0 & 50 & 50 \\
\hline & & \multirow[t]{2}{*}{ Students } & $\mathrm{F}$ & 17 & 11 & 3 & 45 & 27 \\
\hline & & & $\%$ & 17 & 11 & 3 & 45 & 27 \\
\hline \multirow[t]{4}{*}{15} & \multirow{4}{*}{$\begin{array}{l}\text { An adequate set } \\
\text { of evaluation } \\
\text { quizzes or testing } \\
\text { suggestions is } \\
\text { included. }\end{array}$} & \multirow[t]{2}{*}{ Teachers } & $\mathrm{F}$ & 0 & 1 & 0 & 1 & 2 \\
\hline & & & $\%$ & 0 & 25 & 0 & 25 & 50 \\
\hline & & \multirow[t]{2}{*}{ Students } & $\mathrm{F}$ & 19 & 21 & 0 & 28 & 32 \\
\hline & & & $\%$ & 19 & 21 & 0 & 28 & 32 \\
\hline \multirow[t]{4}{*}{16} & \multirow{4}{*}{$\begin{array}{c}\text { The book } \\
\text { provides models } \\
\text { for final } \\
\text { achievement } \\
\text { tests. }\end{array}$} & \multirow[t]{2}{*}{ Teachers } & $\mathrm{F}$ & 2 & 1 & 0 & 1 & 0 \\
\hline & & & $\%$ & 50 & 25 & 0 & 25 & 0 \\
\hline & & \multirow[t]{2}{*}{ Students } & $\mathrm{F}$ & 34 & 37 & 3 & 16 & 10 \\
\hline & & & $\%$ & 34 & 37 & 3 & 16 & 10 \\
\hline
\end{tabular}

The results in the above table indicated that the majority of participants support the statements that are varieties of activities in the text book, $34 \%$ of students strongly agree and $43 \%$ of students agree. Moreover, $50 \%$ of the teachers strongly agree and $25 \%$ of the teachers agree. On the other hand, few of the participants disagree. The interview result also supports these statements.

As it can be seen from Table 3 item 11\&12, majority of the respondents both on the questionnaire and interview agreed that the activities encourage meaningful practice and incorporate individual, pair and group works.

As it can be seen from the above table, item 13,14 and 15, majority of the participants positively support the statements. On the other hand, majority of the respondents disagree with the statement of item 16. The result of this item indicated that the textbook lacked adequate models for final achievement tests. All the interviewed teachers also pointed out that only few sample/model achievement tests are included at the end of some chapters in the text book, but they could not find sufficient models. According to the teachers' suggestions, the sample/model tests included in the text book are dominantly grammar focused.

Table4. Subjects' Perception on the Skills in the Textbook

\begin{tabular}{|c|c|c|c|c|c|c|c|c|}
\hline No & Item & \multicolumn{2}{|c|}{ Respondents } & Strongly & Disagree & Undecided & Agree & Strongly \\
\hline \multirow[t]{4}{*}{16} & \multirow{4}{*}{$\begin{array}{c}\text { The material } \\
\text { provides an } \\
\text { appropriate balance } \\
\text { of the four } \\
\text { language skills }\end{array}$} & \multirow[t]{2}{*}{ Teachers } & $\mathrm{F}$ & 0 & 0 & 0 & 2 & 2 \\
\hline & & & $\%$ & 0 & 0 & 0 & 50 & 50 \\
\hline & & \multirow[t]{2}{*}{ Students } & $\mathrm{F}$ & 15 & 8 & 7 & 40 & 30 \\
\hline & & & $\%$ & 15 & 8 & 7 & 40 & 30 \\
\hline
\end{tabular}


English Textbook in Ethiopia from Teachers' and Students' Perspectives: The Case of Grade Twelve Students' Textbook

\begin{tabular}{|c|c|c|c|c|c|c|c|c|}
\hline \multirow[t]{4}{*}{17} & \multirow{4}{*}{$\begin{array}{l}\text { The reading } \\
\text { passages are } \\
\text { associated with } \\
\text { pre/while/post } \\
\text { reading activities. }\end{array}$} & \multirow[t]{3}{*}{ Teachers } & $F$ & 0 & 0 & 0 & 2 & 2 \\
\hline & & & $\%$ & 0 & 0 & 0 & 50 & 50 \\
\hline & & & $\mathrm{F}$ & 5 & 18 & 0 & 40 & 37 \\
\hline & & Students & $\%$ & 5 & 18 & 0 & 40 & 37 \\
\hline \multirow[t]{4}{*}{18} & \multirow{4}{*}{$\begin{array}{l}\text { The materials for } \\
\text { listening are } \\
\text { accompanied by } \\
\text { background } \\
\text { information } \\
\text { questions and } \\
\text { activities which } \\
\text { help } \\
\text { comprehension. }\end{array}$} & \multirow[t]{2}{*}{ Teachers } & $\mathrm{F}$ & 1 & 0 & 0 & 2 & 1 \\
\hline & & & $\%$ & 25 & 0 & 0 & 50 & 25 \\
\hline & & \multirow[t]{2}{*}{ Students } & $\mathrm{F}$ & 4 & 4 & 25 & 35 & 32 \\
\hline & & & $\%$ & 4 & 4 & 25 & 35 & 32 \\
\hline \multirow[t]{4}{*}{19} & \multirow{4}{*}{$\begin{array}{l}\text { The materials for } \\
\text { spoken English } \\
\text { (dialogues, role } \\
\text { play, } \\
\text { communication } \\
\text { activities etc) are } \\
\text { designed to equip } \\
\text { learns for real life } \\
\text { interaction }\end{array}$} & \multirow[t]{2}{*}{ Teachers } & $\mathrm{F}$ & 0 & 0 & 1 & 1 & 2 \\
\hline & & & $\%$ & 0 & 0 & 25 & 25 & 50 \\
\hline & & \multirow[t]{2}{*}{ Students } & $\mathrm{F}$ & 18 & 10 & 14 & 28 & 30 \\
\hline & & & $\%$ & 18 & 10 & 14 & 28 & 30 \\
\hline \multirow[t]{4}{*}{20} & \multirow{4}{*}{$\begin{array}{l}\text { The textbook pays } \\
\text { attention to writing } \\
\text { activities such as } \\
\text { controlled, guided } \\
\text { and free }\end{array}$} & \multirow[t]{2}{*}{ Teachers } & $\mathrm{F}$ & 0 & 0 & 1 & 1 & 2 \\
\hline & & & $\%$ & 0 & 0 & 25 & 25 & 50 \\
\hline & & \multirow[t]{2}{*}{ Students } & $\mathrm{F}$ & 16 & 10 & 6 & 38 & 30 \\
\hline & & & $\%$ & 16 & 10 & 6 & 38 & 30 \\
\hline
\end{tabular}

As it can be seen from table item 16, the majority of the respondents stated that the skills are treated equally in the materials. Regarding to review whether the reading passages in the materials are associated with pre-while and post reading activities, al large number of students (77\%) and all teachers $(100 \%)$ confirmed that the reading passages are allied with comprehension related questions.

Regarding item 18 in the above table, majority of the respondents suggested that the listening materials are accompanied by background information questions and activities. However, majority of teachers in the open ended questions/comment section indicated that the listening texts of all the units are attached to the last pages of the textbook. They also indicated that when students were asked to listen and do listening activities they directly copy from the text book. As a result, either teachers' jump the listening section or they are expected to prepare listening activities for each unit. Thus, the listening text would have been placed in the teacher's guide.

According to item 19, both the teachers and students indicated that the materials for spoken English are design to equip learners for real life interaction.

Regarding table 4, item 20, the majority of the respondents suggested that the books have paid an adequate attention to writing activities. The results of item 16-20 in the interview are consistent with the questionnaire.

Table5. Subjects' Perception on the structure and vocabulary in the Textbook

\begin{tabular}{|c|c|c|c|c|c|c|c|c|}
\hline No & Item & \multicolumn{2}{|c|}{ Respondents } & Strongly & Disagree & Undecided & Agree & Strongly \\
\hline \multirow[t]{4}{*}{21} & \multirow{4}{*}{$\begin{array}{l}\text { The grammatical } \\
\text { rules are presented in } \\
\text { a logical manner and } \\
\text { in increasing order of } \\
\text { difficulty. }\end{array}$} & \multirow[t]{2}{*}{ Teachers } & $\mathrm{F}$ & 0 & 1 & 0 & 2 & 1 \\
\hline & & & $\%$ & 0 & 25 & 0 & 50 & 25 \\
\hline & & \multirow[t]{2}{*}{ Students } & $\mathrm{F}$ & 12 & 10 & 10 & 38 & 30 \\
\hline & & & $\%$ & 12 & 10 & 10 & 38 & 30 \\
\hline \multirow[t]{4}{*}{22} & \multirow{4}{*}{$\begin{array}{c}\text { There is sufficient } \\
\text { written practice of the } \\
\text { grammatical concepts } \\
\text { that lead to } \\
\text { communicative use } \\
\text { of the language. }\end{array}$} & \multirow[t]{2}{*}{ Teachers } & $\mathrm{F}$ & & 1 & 0 & 2 & 1 \\
\hline & & & $\%$ & 0 & 25 & 0 & 50 & 25 \\
\hline & & \multirow[t]{2}{*}{ Students } & $\mathrm{F}$ & 12 & 8 & 20 & 28 & 30 \\
\hline & & & $\%$ & 12 & 8 & 20 & 28 & 30 \\
\hline
\end{tabular}




\begin{tabular}{|c|c|c|c|c|c|c|c|c|}
\hline \multirow[t]{4}{*}{23} & \multirow{4}{*}{$\begin{array}{c}\text { The vocabulary is } \\
\text { functional, thematic, } \\
\text { authentic, and } \\
\text { practical. }\end{array}$} & \multirow[t]{2}{*}{ Teachers } & $\mathrm{F}$ & 0 & 0 & 1 & 1 & 2 \\
\hline & & & $\%$ & 0 & 0 & 25 & 25 & 50 \\
\hline & & \multirow[t]{2}{*}{ Students } & $\mathrm{F}$ & 15 & 10 & 15 & 32 & 28 \\
\hline & & & $\%$ & 15 & 10 & 15 & 32 & 28 \\
\hline \multirow[t]{4}{*}{24} & \multirow{4}{*}{$\begin{array}{l}\text { The new vocabulary } \\
\text { words are presented } \\
\text { at an appropriate rate } \\
\text { so that the text is } \\
\text { understandable. }\end{array}$} & \multirow[t]{2}{*}{ Teachers } & $\mathrm{F}$ & 1 & 0 & 0 & 2 & 1 \\
\hline & & & $\%$ & 25 & 0 & 0 & 50 & 25 \\
\hline & & \multirow[t]{2}{*}{ Students } & $\mathrm{F}$ & 9 & 16 & 10 & 30 & 35 \\
\hline & & & $\%$ & 9 & 16 & 10 & 30 & 35 \\
\hline
\end{tabular}

As indicated in table 5 above and interview result, majority of the respondents' opinions tended towards the positive. According to the majority of the participants, the vocabulary section of the textbook are well designed.

Table6. Subjects' Perception on the language input in the Textbook

\begin{tabular}{|c|c|c|c|c|c|c|c|c|}
\hline \multirow{2}{*}{$\begin{array}{l}\text { No } \\
25\end{array}$} & \multirow{5}{*}{$\begin{array}{l}\text { Item } \\
\text { The language used in the } \\
\text { textbook is authentic i.e. like } \\
\text { real-life English }\end{array}$} & \multicolumn{2}{|c|}{ Respondents } & \multirow{2}{*}{$\begin{array}{c}\begin{array}{c}\text { Strongly } \\
\text { disagree }(1)\end{array} \\
0\end{array}$} & \multirow{2}{*}{$\begin{array}{c}\text { Disagree } \\
(2) \\
0\end{array}$} & \multirow{2}{*}{$\begin{array}{l}\text { Undecided } \\
\text { (3) } \\
0\end{array}$} & \multirow{2}{*}{$\begin{array}{l}\text { Agree } \\
(4) \\
2\end{array}$} & \multirow{2}{*}{$\begin{array}{l}\text { Strongly } \\
\text { agree }(5) \\
2\end{array}$} \\
\hline & & Teachers & $\mathrm{F}$ & & & & & \\
\hline & & & $\%$ & 0 & 0 & 0 & 50 & 50 \\
\hline & & Students & $\mathrm{F}$ & 9 & 11 & 4 & 40 & 36 \\
\hline & & & $\%$ & 9 & 11 & 4 & 40 & 36 \\
\hline \multirow[t]{4}{*}{26} & \multirow{4}{*}{$\begin{array}{l}\text { The language used is at the } \\
\text { right level of the learners }\end{array}$} & Teachers & $\mathrm{F}$ & 0 & 0 & 1 & 1 & 2 \\
\hline & & & $\%$ & 0 & 0 & 25 & 25 & 50 \\
\hline & & & $\mathrm{F}$ & 15 & 10 & 15 & 32 & 28 \\
\hline & & Students & $\%$ & 15 & 10 & 15 & 32 & 28 \\
\hline \multirow[t]{4}{*}{27} & \multirow{4}{*}{$\begin{array}{l}\text { The progression of grammar } \\
\text { points and vocabulary items is } \\
\text { appropriate }\end{array}$} & \multirow[t]{2}{*}{ Teachers } & $\mathrm{F}$ & 0 & 0 & 0 & 2 & 2 \\
\hline & & & $\%$ & 0 & 0 & 0 & 50 & 50 \\
\hline & & \multirow[t]{2}{*}{ Students } & $\mathrm{F}$ & 9 & 11 & 4 & 40 & 36 \\
\hline & & & $\%$ & 9 & 11 & 4 & 40 & 36 \\
\hline \multirow[t]{4}{*}{28} & \multirow{4}{*}{$\begin{array}{l}\text { The textbook includes } \\
\text { materials for pronunciation } \\
\text { work (e.g. individual sound, } \\
\text { word stress, etc.etc) }\end{array}$} & \multirow[t]{2}{*}{ Teachers } & $\mathrm{F}$ & 1 & 2 & 0 & 1 & 0 \\
\hline & & & $\%$ & 25 & 50 & 0 & 25 & 0 \\
\hline & & \multirow[t]{2}{*}{ Students } & $\mathrm{F}$ & 28 & 34 & 8 & 15 & 15 \\
\hline & & & $\%$ & 28 & 34 & 8 & 15 & 15 \\
\hline
\end{tabular}

Table 6 indicated, majority of the respondents stated that the language used in the textbook is authentic. Approximately, two third of the participants claimed that the language used is in grade 12 text book is at the right level for students' current English ability. Majority of the students and teachers stated that the progression of grammar points and vocabulary items is appropriate. It is understood from these data that most respondents seemed satisfied with the textbook's treatment of linguistic items such as grammatical structures, functions, and vocabulary. Regarding pronunciation in table 6 item $28,62 \%$ of students and $75 \%$ of the teachers revealed that pronunciation work is not included at all. A similar result is also observed considering items 25-28.

Table7. Subjects' Perception on the Subject and Content in the Textbook

\begin{tabular}{|c|c|c|c|c|c|c|c|c|}
\hline No & Item & Respon & & $\begin{array}{c}\text { Strongly } \\
\text { disagree (1) }\end{array}$ & $\begin{array}{l}\text { Disagree } \\
\text { (2) }\end{array}$ & $\begin{array}{l}\text { Undecided } \\
\text { (3) }\end{array}$ & $\begin{array}{l}\text { Agree } \\
\text { (4) }\end{array}$ & $\begin{array}{l}\text { Strongly } \\
\text { agree (5) }\end{array}$ \\
\hline \multirow[t]{4}{*}{29} & \multirow{4}{*}{$\begin{array}{l}\text { The subject and } \\
\text { content of the } \\
\text { textbook is } \\
\text { relevant to } \\
\text { students needs }\end{array}$} & \multirow[t]{2}{*}{ Teachers } & $F$ & 0 & 1 & 0 & 2 & 1 \\
\hline & & & $\%$ & 0 & 25 & 0 & 50 & 25 \\
\hline & & \multirow[t]{2}{*}{ Students } & $\mathrm{F}$ & 9 & 11 & 10 & 38 & 32 \\
\hline & & & $\%$ & 9 & 11 & 10 & 38 & 32 \\
\hline \multirow[t]{4}{*}{30} & \multirow{4}{*}{$\begin{array}{l}\text { There is sufficient } \\
\text { variety in the } \\
\text { subject and } \\
\text { content of the } \\
\text { textbook the } \\
\text { reader to think } \\
\text { about his/her } \\
\text { worldview. }\end{array}$} & \multirow[t]{2}{*}{ Teachers } & $\mathrm{F}$ & 0 & 0 & 0 & 3 & 1 \\
\hline & & & $\%$ & 0 & 0 & 0 & 75 & 25 \\
\hline & & \multirow[t]{2}{*}{ Students } & $\mathrm{F}$ & 6 & 18 & 9 & 40 & 27 \\
\hline & & & $\%$ & 6 & 18 & 9 & 40 & 27 \\
\hline \multirow[t]{4}{*}{31} & \multirow{4}{*}{$\begin{array}{c}\text { The content } \\
\text { contains real-life } \\
\text { issues that } \\
\text { challenge }\end{array}$} & \multirow[t]{2}{*}{ Teachers } & $\mathrm{F}$ & 0 & 0 & 1 & 1 & 2 \\
\hline & & & $\%$ & 0 & 0 & 25 & 25 & 50 \\
\hline & & \multirow[t]{2}{*}{ Students } & $\mathrm{F}$ & 15 & 10 & 15 & 32 & 28 \\
\hline & & & $\%$ & 15 & 10 & 15 & 32 & 28 \\
\hline
\end{tabular}


Based on the data, in Table 7 item 29, the majority of the respondents stated that the content of the textbooks are relevant to the needs of the learners. Besides, $100 \%$ of the teachers and $67 \%$ of the students agreed that there is a variety in the subject and content of the textbooks. Regarding item 31, $75 \%$ of the teachers and $60 \%$ of the students agreed that the text book contains real-life issues that challenge. Similar data has been obtained from the interview.

Table8. Subjects' Perception on the Cultural representation in the Textbook

\begin{tabular}{|c|c|c|c|c|c|c|c|c|}
\hline No & Item & \multicolumn{2}{|c|}{ Respondents } & Strongly & Disagree & Undecided & Agree & Strongly \\
\hline \multirow[t]{4}{*}{32} & \multirow{4}{*}{$\begin{array}{c}\text { The book } \\
\text { represents people } \\
\text { in a fair and } \\
\text { equal way }\end{array}$} & \multirow[t]{2}{*}{ Teachers } & $\mathrm{F}$ & 0 & 0 & 0 & 2 & 2 \\
\hline & & & $\%$ & 0 & 0 & 0 & 50 & 50 \\
\hline & & \multirow[t]{2}{*}{ Students } & $\mathrm{F}$ & 5 & 2 & 0 & 50 & 43 \\
\hline & & & $\%$ & 5 & 2 & 0 & 50 & 43 \\
\hline \multirow[t]{4}{*}{33} & \multirow{4}{*}{$\begin{array}{l}\text { The topics are } \\
\text { culturally } \\
\text { appropriate for } \\
\text { the students. }\end{array}$} & \multirow[t]{2}{*}{ Teachers } & $\mathrm{F}$ & 0 & 1 & 0 & 2 & 1 \\
\hline & & & $\%$ & 0 & 25 & 0 & 50 & 25 \\
\hline & & \multirow[t]{2}{*}{ Students } & $\mathrm{F}$ & 15 & 9 & 5 & 30 & 36 \\
\hline & & & $\%$ & 15 & 9 & 5 & 30 & 36 \\
\hline
\end{tabular}

As shown in table 8 item $32,100 \%$ of the teachers and $93 \%$ of the students and all interviewed teachers responded that the textbook treat people in fair and equal way. The participants were also requested to forward their view whether the topics are culturally appropriate. To this end, $75 \%$ of the teachers, $66 \%$ of the students and majority of interviewees judged that the topics are in harmony with learners' cultural background.

Table9. Subjects' overall Perception towards the Textbook

\begin{tabular}{|c|c|c|c|c|c|c|c|c|}
\hline No & Item & \multicolumn{2}{|c|}{ Respondents } & Strongly & Disagree & Undecided & Agree & Strongly \\
\hline \multirow[t]{4}{*}{34} & \multirow{4}{*}{$\begin{array}{c}\text { The book } \\
\text { satisfies students' } \\
\text { interest of } \\
\text { learning English } \\
\text { language }\end{array}$} & \multirow{2}{*}{ Teachers } & $\mathrm{F}$ & 0 & 1 & 0 & 2 & 1 \\
\hline & & & $\%$ & 0 & 25 & 0 & 50 & 25 \\
\hline & & \multirow[t]{2}{*}{ Students } & $\mathrm{F}$ & 8 & 8 & 6 & 46 & 32 \\
\hline & & & $\%$ & 8 & 8 & 6 & 46 & 32 \\
\hline \multirow[t]{4}{*}{35} & \multirow{4}{*}{$\begin{array}{l}\text { The book is } \\
\text { suitable for grade } \\
12 \text { Ethiopian } \\
\text { students }\end{array}$} & \multirow[t]{2}{*}{ Teachers } & $\mathrm{F}$ & 1 & 0 & 0 & 1 & 2 \\
\hline & & & $\%$ & 25 & 0 & 0 & 25 & 50 \\
\hline & & \multirow[t]{2}{*}{ Students } & $\mathrm{F}$ & 12 & 10 & 9 & 39 & 30 \\
\hline & & & $\%$ & 12 & 10 & 9 & 39 & 30 \\
\hline
\end{tabular}

As observed in table 9 Item $34,75 \%$ of the teachers and $78 \%$ of the students feel that the text book for grade 12 satisfy the learning interest of the students. In addition, $75 \%$ of the teachers and $69 \%$ of the students judged that the text book is suitable to its users. Similar result has been obtained from the interview.

\section{CONCLUSIONS AND RECOMMENDATIONS}

The purpose of this study was to assess the perception of teachers' and students' towards Grade 12 English for Ethiopia student's Textbook. A survey questionnaire and semi-structured interview were used in this study to elicit the perspectives of 4 English language teachers and 100 students in Hawassa Addis Ketema Secondary and Preparatory School. The questionnaire consisted of 35 items grouped under 9 main categories: the general layout and physical appearance, objectives, activities and tasks, Skills, structure and vocabulary, language input, subject and content, cultural representation and on the overall Perception towards the Textbook. Semi-structured interview also designed and four teachers were interviewed to strengthen the data collected through questionnaire. The close ended questionnaire was analyzed quantitatively. Whereas, the open ended questionnaire and the semistructured interview were analyzed qualitatively. The findings of this research study were generally in favour of the textbook except some sub-items.

Conclusions: Based on the results obtained from questionnaire and interview the following conclusions are drawn:

1. The Twelve Grade English Language Textbook for Ethiopia satisfies teachers' and students' regarding on its layout and physical appearance. However, the size of the textbook is not suitable to the students to handle and sufficient numbers of vocabulary list/ glossary are not added. 
2. The textbook in question satisfies teachers' and students' expectations regarding its objectives. However, the objectives stated in the text book cannot be covered with in the allocated time.

3. The textbook in question satisfies teachers' and students' regarding its activities and tasks. However it lacks in providing models for final achievements.

4. Concerning the skills, the textbook satisfies the participants. However, the listening text is placed at the end of the student's text book which would have been put in the teacher's guide.

5. The textbook satisfies teachers' and students' regarding on its structure and vocabulary presentation.

6. The textbook in question satisfies teachers' and students' expectations regarding its language input. However, pronunciation contents are neglected.

7. Significant numbers of topics and contents are included in the textbook and in harmony with the learners' interest and culture.

8. Despite some short comings, the textbook has many strong sides as it has been mentioned above.

Recommendations: Based on the results obtained from this study, the following points are recommended:

1. An appropriate glossary has to be added at the end of the textbook for the benefit of both teachers and students.

2. Sufficient time should be allocated to cover the stated objectives.

3. Sufficient models should be included to help students practice for final model exams or entrance exams.

4. The listening text should be placed to the teacher's guide.

5. Appropriate pronunciation tasks/contents should be included.

\section{REFERENCES}

Abdulrahman Ali M. Alamri(2008). An Evaluation of the Sixth Grade English Language Textbook for Saudi Boys' Schools: MA Thesis. King Saud University.

Barber, (1993). The English Language a Historical Instruction. Galasow: Cambridge University Press.

Brown, J.D. and Rogers, T.S. (2002).Doing second language research. Oxford: Oxford University Press.

Gay, L. R. and Airasian, P. (2000). Educational Research: Competencies for Analysis and Application. $6^{\text {th }}$ Edition, New Jersey: Prentice- Hall.

HailuAbera. (2008). A Study on the English for Ethiopia Grade 11 Students' Books: The Case of WelduNugus Secondary School-Quiha' (MA Thesis Unpublished) Addis Abeba: Addis Ababa University.

Leslie E. Sheldon.(1998).Evaluating ELT textbooks and Materials: ELT Journal Volume 42/4 October 1988 - Oxford University Press 1988

Lynch, B. K. (1996). Language Program Evaluation: Theory and Practice. Cambridge: Cambridge University Press.

Richards, J. (2001). Curriculum Development in Language Teaching. Cambridge: Cambridge University Press.

Ur, Penny (2006). A Course in Language Teaching: Practice and Theory. 13th printing. Cambridge: Cambridge University Press.

\section{AUTHOR's BIOGRAPHY}

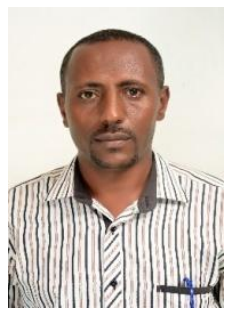

AbebeTilahun, Lecturer, School of Languages and Communication Studies, Program of English Language and Literature, Hawasa University, Hawassa, Ethiopia, received MA in Teaching English as a Foreign Language from Addis Ababa University, Addis Ababa, Ethiopia. He is an expert teacher in facilitating students by using interactive discussions and encourages students learn and apply concepts in Communicative English, Functional Grammar and improving Writing Skills. 